\title{
Aktanterne har udspillet deres rolle
}

\author{
SUSANNE ANNIKKI KRISTENSEN \\ Institut for Kommunikation, Aalborg Universitet, Danmark
}

\begin{abstract}
This paper discusses some fundamental issues regarding syntactic analysis and semantic roles. Traditionally, a syntactic analysis has as its point of departure a morphological analysis claiming a one-to-one correspondence between a morphological form and a syntactic function. In the paper, I argue that this procedure must be reversed. A morphological analysis is only useful if one wants to describe morphological languages such as Finnish and German, whereas topological languages such as Danish and English only reveal a rudimentary morphological system. In my opinion case as well as topology is a particular device for syntactic signification in a specific language, whereas syntax is universal; at least if the syntactic description is based on a formal, universal theory. A very short introduction to such a universal theory on syntax is given in the paper, namely the so called Epi-Formal Analysis of Syntax $(\operatorname{EFA}(X))$.
\end{abstract}

By claiming the existence of semantic roles in sentences one implicitly claims that a sentence describes a scenario and the semantic roles are that the actors on the scene. The problem is that these semantic roles are sentence internal entities based on definitions that are internal to the theory resulting in entirely internal explanations on the semantics of the sentence. An agent is an agent because the role acts as an agent in the scenario described by the sentence. According to $\operatorname{EFA}(X)$, that is a formal theory based on external definitions of the theoretical concepts, a language user's mental representations of the entities of the world and the relations between these entities as mental concepts in an utterance. The concepts are composed of the language user's mental images of the entities combined with mental images of the sounds referring to these entities. An utterance is a structure of concepts, which is expressed by sentences and constituents, so a sentence is an expression of the language user's mental images of (a small part of) the world. In this way, the theoretical concepts of $\operatorname{EFA}(X)$ are defined externally providing external explanations of the semantics of the sentence. If

Tidsskrift for Sprogforskning • Årgang 4 • Nr. 1-2 • 2006, pp. 55-91 
one agrees in the general assumption that the world consists of entities in relations and that sentences are expressions of the language user's mental images of the entities of the world, there is no need for sentence internal concepts like semantic roles to explain the semantics of the sentence.

\section{INTRODUKTION}

I denne artikel vil jeg dels plædere for, at den traditionelle fremgangsmåde ved syntaktiske beskrivelser erstattes af en alternativ metode og dels demonstrere, at semantiske roller ikke er nødvendige størrelser i en sproglig beskrivelse. Dette vil jeg gøre ved kort at behandle den lingvistiske traditions definitioner af de tre elementer i den oprindelige titel for lingvistkollokviet på Statsbiblioteket (2006): "Kasus, sætningsled og semantiske roller". Derefter vil jeg præsentere alternative definitioner og et mere formelt syn på syntaks og grammatik som ramme for den sproglige beskrivelse.

\section{KASUS}

Kasus har gennem tiden haft en særdeles fremtrædende rolle i de deskriptive beskrivelser af naturlige sprogs morfologi; som Fillmore påpeger (Fillmore 1968: 3) har kasus og morfologiske beskrivelser i øvrigt haft en så fremtrædende rolle, at der i de deskriptive grammatikker kun har været levnet plads til to-tre siders syntaktiske beskrivelser, mens de morfologiske beskrivelser har okkuperet resten af fremstillingerne.

Denne tilsidesættelse af syntaksen skyldes angiveligt, at man har forudsat en entil-en-korrespondance mellem kasus og sætningsled, hvilket afspejles i traditionelle definitioner af kasus og kasussystemets elementer:

Case. Inflectional category, basically of nouns, which typically marks their role in relation to other parts of the sentence. (Matthews 1997: 46)

Nominative. Case whose basic role, or one of whose basic roles, is to indicate a subject of all classes of verb. (Matthews 1997: 244)

Accusative. Case whose basic role, or one of whose basic roles, is to mark a direct object. (Matthews 1997: 5) 


\title{
AKTANTERNE HAR UDSPILLET DERES ROLLE
}

Kasus er ifølge definitionen en morfologisk kategori, der bruges til at angive et sprogligt elements rolle i en sætning, upåagtet at begrebet 'rolle' ikke defineres (og ikke nødvendigvis kan antages at være intuitivt forståeligt). De traditionelle definitioner af kasussystemets elementer demonstrerer ganske godt, at præmissen ved de traditionelle morfologiske beskrivelser er en-til-enkorrespondance mellem form og funktion. En sætning, hvori der indgår nominativ, akkusativ og dativ, har således let kunnet bestemmes som en sætning indeholdende et subjekt, et objekt og et dativobjekt / indirekte objekt, som det ses i følgende beskrivelse i en deskriptiv grammatik:

I en sætning som sie schenkte ihrem Mann einen Ring bestemmes [...] ved den grammatiske analyse akkusativen som direkte objekt, dativen som indirekte objekt, dvs. som et led, der er underordnet verbum + direkte objekt. (Jørgensen 1970: 45)

Det hedder ligeledes:

\begin{abstract}
Grammatisk klart adskilt fra de hidtil behandlede tilfælde af dativobjekt er dativleddet i sætninger som er half seinem Freund. Her er dativen eneste objekt, i umiddelbar tilknytning til verbet, på ganske samme måde som akkusativen er eneste objekt for verbet i er unterstützte seinen Freund. Kun styrelsesforholdet er forskelligt: unterstützen styrer akkusativ, helfen styrer dativ. Hvad det semantiske angår, synes imidlertid dette eneste dativobjekt at kunne bringes $\mathrm{i}$ forbindelse med det omtalte indirekte dativobjekt [...]. (Jørgensen 1970: 47)

Dermed er dativen som objekt til en vis grad afgrænset over for akkusativen: akkusativobjektet kan være en række forskellige 'logiske' objekter, deriblandt også 'retningsobjekt', mens dativobjektet så godt som altid er 'retningsobjekt'. (Jørgensen 1970: 47-48)
\end{abstract}

Ifølge ovenstående karakteristik er der en direkte sammenhæng mellem dativ og dativobjekt / indirekte objekt. Dativobjektet karakteriseres endvidere som et retningsobjekt (hvad det så helt præcist er?), der som ad hoc-element ikke defineres yderligere i bogen, men dette er angiveligt en karakteristik, som i visse tilfælde også passer på akkusativobjektet / det direkte objekt. Dermed er der for mig at se ikke klare kriterier for at bestemme et såkaldt retningsobjekt som enten dativ- eller akkusativobjekt; analytikerens fornemmelse synes at være eneste kriterium. Det er desuden problematisk, at det tillades, at indirekte objekter optræder i konstruktioner, uden at der også forekommer direkte objekter, for 
hvad bliver da kriterierne for at udpege leddene som led ud over morfologien, og hvordan bliver det muligt at lave sammenlignende studier mellem sprog som henholdsvis udtrykker og ikke udtrykker dativ?

Sætningsled, der defineres semantisk som bl.a. retningsobjekter, og beskrivelser, der tillader et indirekte objekt at forekomme, uden at der også forekommer et direkte objekt, vidner for mig at se om, at syntaksen kun i ringe grad er baseret på en modsigelsesfri, udtømmende og den simplest mulige teori, som Hjelmslev foreskriver det (jf. Hjelmslev 1943), ligesom det tillades, at der indføres ad hocelementer fra sidelinjen til at beskrive de syntaktiske elementer.

Når der har været en en-til-en-korrespondance mellem en morfologisk form og en syntaktisk funktion, synes det umiddelbart unødvendigt med lange udredninger af de specifikke sprogs syntaktiske strukturer, idet den morfologiske beskrivelse så at sige også har udgjort den syntaktiske beskrivelse, hvorfor de syntaktiske beskrivelser givetvis kun har fået tildelt en ringe plads i de deskriptive grammatikker. Denne deskriptive behandling af sproglig form og funktion er dog ikke uproblematisk, og tilgangen har for mig at se mindst tre svage punkter. For det første risikerer man, at den syntaktiske beskrivelse og de bagvedliggende syntaktiske grundbegreber bliver a-teoretiske, ureflekterede og baserede på ad hoc-elementer: et sprogligt element er subjekt, fordi det udtrykker nominativ, og det sproglige element udtrykker nominativ, fordi det er subjekt.

For det andet kan fremgangsmåden, såfremt man tilslutter sig den, være effektiv, når beskrivelsens genstand er, hvad man kunne kalde morfologiske sprog (jf. nedenfor) som fx latin eller finsk, hvor kasussystemerne er rigt udbygget og mere eller mindre gennemsigtige, men fremgangsmåden fejler afgørende, når beskrivelsen vedrører topologiske sprog som dansk og engelsk, hvor kasussystemet blot er rudimentært og derfor kun realiseres delvist - nok udtrykker pronominerne de tre tilgængelige kasus i dansk: nominativ, akkusativ og genitiv, men substantivernes nominativ- og akkusativform er sammenfaldende og derfor ikke syntaktisk betegnende.

For det tredje finder jeg, at det er en farlig strategi at sætte form lig med funktion, idet en given form i visse sprog kan have mange funktionsmuligheder. I substantivernes 1. deklination i latin, er der synkretisme mellem genitiv- 
singularis, dativ-singularis og nominativ-pluralis, hvilket demonstreres i følgende konstruktion fra en pædagogisk lærebog:

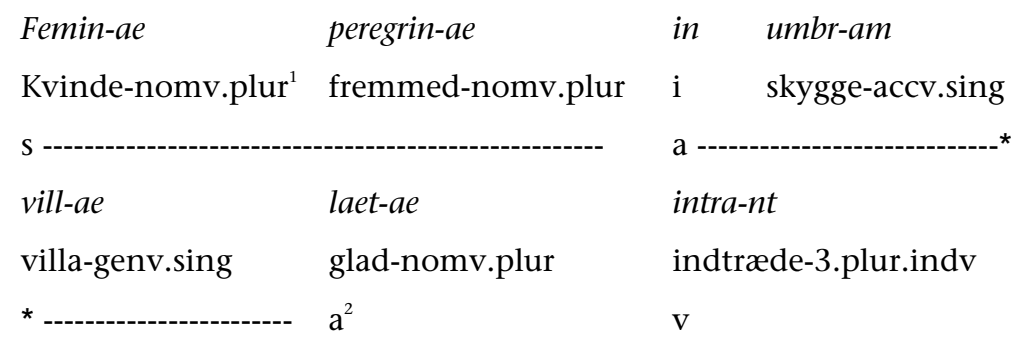

'De fremmede kvinder træder glade ind i villaens skygge.'

(Bolt-Jørgensen 1998: 19)

I sætningen optræder et væld af adjektiver og substantiver under 1. deklination, men de mest interessante i denne forbindelse er adjektiverne og substantiverne, der udtrykker de sammenfaldende former: feminae, peregrinae, villae og laetae. Med de sammenfaldende former i de tre kasus er det ikke umiddelbart muligt at afgøre, om fx feminae peregrinae udtrykker dativ-singularis eller nominativpluralis, og derfor er det nødvendigt at foretage en opklarende syntaktisk beskrivelse (baseret på frekvensundersøgelser eller transitivitet), inden den morfologiske beskrivelse (jf. nedenfor). Under alle omstændigheder er der ikke en en-til-en-korrespondance mellem formen -ae og en specifik syntaktisk funktion, hvilket giver anledning til at afvise tanken, at form er lig med en specifik funktion i et sprog.

Gennem tiden har der desuden sideløbende med de deskriptive studier af specifikke sprog været en mere eller mindre imperialistisk tendens til, at et sprogs kasussystem er blevet sat som norm for beskrivelsen af et andet sprogs kasussystem for derigennem at påvise universalier. Denne tilgang har især nydt fremme i deskriptive grammatikker frem til en gang i 1800-tallet, hvor det latinske kasussystem med større eller mindre held har været brugt som rettesnor ved beskrivelsen af andre sprogs kasussystemer. Fillmores vidunderligt sarkastiske henvisning til Jespersen (1924, The Philosophy of Grammar) demonstrerer dels udbredelsen af denne fremgangsmåde og dels skeptikernes syn herpå: 
We have probably all enjoyed sneering, with Jespersen, at his favourite 'bad guy', Sonnenschein, who, unable to decide between Latin and Old English, allowed modern English teach to be described as either taking a dative and an accusative, because that was the pattern for Old English toecan, or as taking two accusatives, in the manner of Latin doceo and German lehren. (Fillmore 1968: 5)

Trods det åbenlyst uhensigtsmæssige i dette forehavende er den dog ikke blot et udtryk for fortidens synder og uvidenhed. For nyligt stiftede jeg bekendtskab med noget nyt undervisningsmateriale: Fra ord til saetning. En introduktion til almen grammatik (Milling, Nedergaard og Norsk 2004), som er produceret til brug i gymnasieskolen til faget Almen sprogforståelse. Materialet har et klart pædagogisk sigte, nemlig at give eleverne i ungdomsuddannelserne en større forståelse for almen grammatik ved at introducere dem for dansk grammatik. Om materialet når sit mål er tvivlsomt, idet det latinske kasussystem bruges som norm for beskrivelsen af det danske kasussystem og den danske syntaktiske struktur, og således får det indirekte objekt følgende karakteristik:

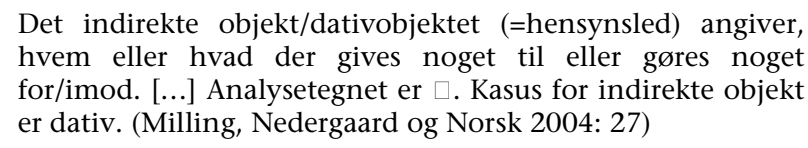

Dansk har ikke længe udtrykt dativ, og derfor er det problematisk at anføre noget sådant i et undervisningsmateriale, der skal give eleverne større indsigt $\mathrm{i}$ og forståelse for grammatik. Fremgangsmåden er dog ikke enestående men skyldes, at de imperialistiske tendenser endnu ikke er udryddet helt fra de deskriptivt orienterede grammatiske fremstillinger.

Et helt tredje aspekt ved kasusbeskrivelserne har været, at visse teoretikere har været villige til at anerkende usynlige kasus eller ikke-realiseret kasus, hos Fillmore kaldet deep-structure kasus; kasus som antages at være universelle. Hos Fillmore anvendes kasusbegrebet dog $\mathrm{i}$ en alternativ betydning $\mathrm{i}$ forhold til traditionelle grammatikere som fx Jespersen (1924), der kun anerkender og anvender begrebet 'kasus' om den synlige morfologiske form (jf. Fillmore 1968: 19-20). For Fillmore (og kasusgrammatikerne med ham) er deep-structure kasus dog et spørgsmål om såkaldte "intrasentence relationships": 


\begin{abstract}
It seems to me that if there are recognizable intrasentence relationships of the types discussed in the studies of case systems (whether they are reflected in case affixes or not), that if these same relationships can be shown to be comparable across languages, and that if there is some predictive or explanatory use to which assumptions concerning the universality of these relations can be put, then surely there can be no meaningful objection to using the word case, in a clearly understood deep-structure sense, to identify these relationships. (Fillmore 1968: 20)
\end{abstract}

Fillmore anvender således termen 'kasus' om en såkaldt underliggende syntaktisk-semantisk relation mellem sætningens størrelser (Fillmore 1968: 21), og han anser denne relation for en realitet også i sprog, som ikke har synlige morfologiske kasus, idet han tilslutter sig Velten (1962, On the functions of French de and $\grave{a}$ ) der afviser, at præpositionsfraser og kasus skal behandles forskelligt. Jeg kan til fulde tilslutte mig Veltens syn, men jeg mener ikke, at det nødvendigvis bør føre til, at man skal acceptere usynlige kasusrelationer i sprog uden morfologiske kasus. Topologiske sprogs præpositionsforbindelser og morfologiske sprogs spatiale kasus er for mig at se snarere er et spørgsmål om på den ene side forskellige måder at angive adverbielle konstituenter og dermed at angive syntaktisk signifikation (jf. nedenfor), og på den anden side at angive efterstillede specifikationer af substantiver. Jeg foretrækker således at reservere begrebet kasus til angivelse af morfologisk signifikation, idet anvendelsen af kasusbegrebet i Fillmores abstrakte forstand for mig at se medfører, at begrebet mister sin betydning. Således tilslutter jeg mig Cassidys forsøg på at redde kasusbegrebet ud af den abstrakte sump (jf. Fillmore 1968: 20).

\title{
2.1. Delkonklusion
}

I det foregående har jeg behandlet nogle af de aspekter ved traditionens syn på kasus. For de deskriptivt orienterede grammatikere er udgangspunktet, at der er en en-til-en-korrespondance mellem form og funktion, hvorved det ikke er nødvendigt at formulere konsistente syntaktiske teorier for at beskrive naturlige sprog - kasus udpeger den syntaktiske konstituent. Der har desuden været gjort forskellige forsøg på at formulere universelle teorier om kasusbetydning, og ét sprogs kasussystem - som oftest det latinske - har været brugt som model ved beskrivelse af andre sprogs kasussystemer. Andre teoretikere har været villige til at acceptere usynlige kasus ved sprog som ikke morfologisk udtrykker kasus - i denne sammenhæng har kasusbegrebet været anvendt om en syntaktisk- 
semantisk relation mellem en konstruktions konstituenter. Jeg har ligeledes behandlet nogle af de problemer, som traditionens syn på kasus kan siges at medføre.

\section{SATNINGSLED ${ }^{3}$}

Jeg vil altså plædere for, at man ved sproglige beskrivelser skal tage udgangspunkt i syntaksen og derefter behandler morfologien frem for omvendt, idet man ud fra en morfologisk form ikke automatisk kan udlede den syntaktiske funktion.

Inden valget af et syntaktisk beskrivelsesapparat må man dog først afklare, om den syntaktiske beskrivelse blot skal tjene til at benævne de syntaktiske størrelser, eller om beskrivelserne skal have forklaringskraft i forhold til en teoretisk problemstilling; i det første tilfælde vælges et deskriptivt beskrivelsesapparat, i det andet et formelt. I den lingvistiske tradition har der været mange eksempler på deskriptivt beskrevne konstituenter, og der synes at være en vis enighed om, at konstituenterne kan defineres som følger:

Subject. A term used in the analysis of grammatical functions to refer to a major constituent of sentence or clause structure, traditionally associated with the 'doer' of an action [...]. (Crystal 1980: 369)

Verbal. A term used in the grammatical classification of words, to refer to a class of traditionally defined as "doing" or "action" words (a description which has been criticized in linguistics, largely on the grounds that many verbs do not 'act' in any obvious sense, e.g. seem, be). The formal definition of a verb refers to an element which can display morphological contrasts of tense, aspect, voice, mood, person and number. Functionally, it is the element which, singly or in combination with other verbs (i.e. 'verb phrase') is used as the minimal predicate of a sentence, co-occuring with a subject [...]. (Crystal 1980: 409-410)

Object. A term used in the analysis of grammatical functions to refer to a major constituent of sentence or clause structure, traditionally associated with the 'receiver' or 'goal' of an action [...]. (Crystal 1980: 266)

Konstituenterne defineres som oftest i traditionen vha. semantik (dvs. semantiske roller) eller morfologi (jf. verbaldefinitionen), og subjektet defineres således i ovenstående som den 'handlende', objektet som 'modtager' eller 'mål' og verbalet som 'handlingen' med visse morfologiske kendetegn, med de forbehold, som Crystal med rette tager, når det gælder verbalets semantik. 
En triviel indvending mod sådanne definitioner er, at der i hverken passive konstruktioner eller eksistentialkonstruktioner indgår en handlende part - det ville i så fald være sneen, som får sneen til at sne (!) i en konstruktion som: det sner, og konsekvensen af den traditionelle, semantikbaserede subjektsdefinition må være, at der i sådanne konstruktioner ikke forekommer subjekter. Dette står $\operatorname{dog}$ i kontrast til fx Diderichsens syn på sætninger og herunder neksusrelationen, der fordrer tilstedeværelsen af et subjekt og et finit verbal (jf. Diderichsen 1946 (1971): 142).

Jeg går grundlæggende set ikke ind for at definere de grammatiske termer vha. semantik, hvilket skyldes, at for mange sætningskonstruktioner ikke vil kunne beskrives vha. et semantisk defineret beskrivelsesapparat - ovenstående eksempel demonstrerer dette med al tydelighed. Derimod så jeg hellere, at én af de grammatiske termer blev defineret pragmatisk (jf. nedenfor) og gerne med inddragelse af sprogbrugeren, således at denne kan få plads i den syntaktiske teori, og teorien dermed ville kunne afspejle, at sprog bruges til kommunikation mellem sprogbrugere. Desuden så jeg gerne, at definitionerne af de grammatiske termer inddrog relationen mellem termerne for at tilgodese, at sætninger består af strukturer i indbyrdes afhængighed (jf. nedenfor).

Den deskriptive, syntaktiske beskrivelses opgave er at benævne sætningens konstituenter, men den har ingen forklaringskraft $i$ forhold til teoretiske spørgsmål. Jeg anser i tilslutning til Chomsky (2000: 5) de deskriptive beskrivelser af sproglige konstruktioner for beskrivelser af produkter af den menneskelige mentale sprogevnes arbejde, og således anser jeg de deskriptive beskrivelser for uinteressante, med mindre de sættes i forbindelse med en generel og gerne en formel sprogteori.

Der findes et væld af mere eller mindre formelle sprogteorier i verden. Den mest prominente er nok Noam Chomskys generativisme, som det dog vil være for omfattende at redegøre grundigt for, hvorfor jeg blot vil foretage en opsummerende karakteristik af aspekter ved Chomskys syntaktiske beskrivelser. Chomskys grundlæggende tese er i såvel New Horizons in the Study of Language and Mind (Chomsky 2000) (herefter New Horizons ...) som i tidligere værker, at sprog er et biologisk objekt eller et organ (Chomsky 2000: 4), der på lige fod med andre af menneskets indre organer kan udvikle sig, og dette organ bør derfor 
kunne beskrives vha. naturvidenskabelige metoder. Udgangspunktet er, at mennesket fra fødslen er udstyret med en universalgrammatik (herefter UG), der i takt med barnets erfaringer med sprog udvikles til en sprogspecifik grammatik, og det er teoretikerens opgave at beskrive denne udvikling. Set i denne ramme bliver beskrivelserne af de sproglige konstruktioner interessante, idet de bliver produktet af den fuldt udviklede sprogspecifikke grammatik, der adskiller sig fra andre sprogspecifikke grammatikker. Termerne 'sprog' og 'sprogligt udtryk' defineres efterfølgende:

\begin{abstract}
Within these theories, there is a fundamental concept that bears resemblance to the common-sense notion "language": the generative procedure that forms structural descriptions (SDs), each a complex of phonetic, semantic, and structural properties. Call this procedure an I-language, a term chosen to indicate that this conception of language is internal, individual, and intensional [...]. We may take the linguistic expressions of a given I-language to be the SDs generated by it. A linguistic expression, then is a complex of phonetic, semantic, and other properties. (Chomsky 2000: 26)
\end{abstract}

Sprog er i den chomskyanske forstand en procedure, der former 'strukturelle beskrivelser' ("SDs") eller sproglige udtryk bestående af et kompleks af 'fonetiske, semantiske og strukturelle egenskaber'. Jeg antager, at de sproglige udtryk er mentale repræsentationer, idet sproglige udtryk kan manifesteres bl.a. verbalt og skriftligt vha. 'særlige signaler' (“particular signals”, jf. Chomsky 2000: 78).

I The Minimalist Program (Chomsky 1995) (herefter MP) såvel som i teorierne fra og med Government and Binding (Chomsky 1981) anvendes en træstruktur bestående af binære par, det såkaldte 'X-bar-system' ("X-bar theory"), ${ }^{4}$ som formelt sprog til beskrivelse af sproglige konstruktioner. Det er i forhold til størrelsernes indplacering i X-bar-systemet, at konstituentkategorierne 'subjekt' og 'objekt' defineres:

The specifier of IP is the subject of IP; the nominal complement of VP is the object of VP. (Chomsky 1995: 55)

Disse definitioner forudsætter, at subjektet flytter fra grundstrukturen (dvs. VP længst til højre i træstrukturen) til IP's specificerer-position, mens objektet forbliver i grundstrukturen. Definitionernes udformning skyldes formodentlig, at X-bar-systemet er formuleret med engelsk som eksempelsprog, og i netop 
engelsk vil subjektstørrelsen flytte til IP, mens objektet "bliver hjemme" i grundstrukturen. Beskrivelsen af de sproglige strukturer forudsætter således, at de sproglige elementer flytter op i strukturen fra de leksikalske projektioner til de funktionelle (så som IP, AgrP osv.) - dvs. længere mod venstre - hvor de gennem tjekningsteorien får deres grammatiske egenskaber tjekket. Tjekningen af de grammatiske informationer siges at foregå ved de funktionelle projektioners tiltrækning af de leksikalske elementer og deres grammatiske informationer i enten 'synlig' ("overt") eller 'usynlig' ("covert") syntaks (Chomsky 1995: 229). Stærke træk medfører synlig syntaktisk variation, mens svage træk ikke påvirker syntaksen.

Jeg har andetsteds problematiseret, at begrebet 'træk' har en så central betydning for den sproglige beskrivelse i generativismen; dette især, når det ikke præciseres, i hvilken betydning begrebet anvendes når ikke i den traditionelle fonologiske forstand (jf. Kristensen 2004 samt Götzsche 1994). Dette aspekt skal jeg derfor lade upåtalt her, og i stedet koncentrere mig om proceduren ved den syntaktiske beskrivelse indenfor generativismen. For det første er det for mig at se problematisk med Chomskys stærke fokusering på ledfølge, mens forhold som kasus reduceres til at være en defekt ved sprog (Chomsky 2000: 12). For mig at se er både ledfølge og kasus måder at angive syntaktisk signifikation (jf. nedenfor), hvorfor ledfølge og morfologi må anses for lige "værdige" i den syntaktiske struktur. Chomskys stærke fokusering på ledfølge giver problemer ved beskrivelsen af morfologiske sprog, hvor ledfølgen kun spiller en mindre rolle. I sprog som latin, finsk og til dels også tyrkisk er ledfølgen mere fleksibel end i fx engelsk, men denne friere ledfølge skal dog beskrives gennem det rigide X-barsystem, og for at det skal lykkes, må en hel del (u)synlige flytninger accepteres flytninger der skal sikre, at den mest frekvente tyrkiske ledfølge subjekt-objektverbal kan beskrives med udgangspunkt i X-bar-systemets grundstruktur med den universelle ledfølge subjekt-verbal-objekt (jf. Kristensen 2001). Den stærke fokusering på ledfølge er derfor for mig at se en risikabel position at antage, eftersom det nødvendigvis må medføre accepten af tanken om flytninger - der endda kan være usynlige - for at få beskrivelsen til at passe med de natursproglige forhold.

Desuden er det for mig at se ikke helt indlysende, hvad det egentlig er, X-barsystemet skal beskrive. Som tidligere nævnt defineres begrebet 'sprog' i den 
chomskyanske generativisme som en procedure, der former strukturelle beskrivelser, og disse antages (af $\mathrm{mig}$ ) at være mentale repræsentationer af et sprogligt udtryk. Den faktiske manifestation af det sproglige udtryk kan endvidere siges at være et anliggende for performance-systemerne (hjulpet på vej af komputationssystemet), men disse behandles ikke yderligere i hverken MP eller New Horizons ..., ligesom forholdet mellem det faktiske sproglige udtryk og den mentale repræsentation heller ikke behandles. Hvordan man kommer fra den strukturelle beskrivelse til det faktiske sproglige udtryk og omvendt behandles således ikke, og det kan derfor være svært at afgøre, hvad X-barsystemet egentlig repræsenterer: faktiske sproglige udtryk eller strukturelle beskrivelser? Hvis det er strukturelle beskrivelser - hvilket er det mest sandsynlige, målet for Chomskys teori taget i betragtning - så kunne det hævdes, at Chomskys generativisme ikke behandler natursproglige konstruktioner men blot formaliserede konstruktioner. Hvis det derimod er faktiske sproglige udtryk, som beskrives vha. X-bar-systemet, så kan det være svært at se forbindelsen mellem X-bar-systemet og den overordnede sprogteori, idet relationen mellem det faktiske sproglige udtryk og den strukturelle beskrivelse som nævnt ikke er klarlagt.

Til trods for disse kritikpunkter til Chomskys generativisme finder jeg alligevel teorien yderst interessant, idet han forsøger at forklare, hvordan det i det hele taget er muligt for mennesket at producere og at tilegne sig sprog, og i den ramme bliver de sproglige beskrivelser interessante, idet de tjener til be- eller afkræftelse af de grundlæggende teser. Det samme gør sig gældende for en anden formel teori, nemlig Lexical Functional Grammar (herefter LFG), der er formuleret af den tidligere generativist Joan Bresnan (2001). LFG vil ligesom den chomskyanske generativisme beskrive en sprogbrugers ubevidste viden om sit modersmåls grammatik, men måden hvorpå denne beskrivelse skal foregå divergerer mellem de to generative teorier.

I LFG opereres der med tre interagerende sproglige dimensioner kaldet henholdsvis 'argumentstruktur' ("argument structure"), 'konstituentstruktur' ("constituent structure") og 'funktionel struktur' ("functional structure") (herefter forkortet 'a-', 'c-' og 'f-struktur'). De tre dimensioner arbejder parallelt (Neidle 1996: 224), men dette på en sådan måde, at f-strukturen, der behandler grammatiske strukturer og funktioner, antages at fungere som bindeled mellem 
de to andre sproglige dimensioner, idet forskellige "mapping"-procedurer hævdes at sikre, at informationerne fra a- og c-strukturen relateres til fstrukturen for yderligere behandling og fortolkning.

Det forudsættes desuden, at universalgrammatikken er opbygget efter et relationelt design, der bl.a. får betydning for repræsentationen af den syntaktiske struktur i c-strukturen. I modsætning til Chomskys fikserede placering af subjektet og objektet i forhold til specificerer- og komplementpositionerne i den binære træstrukturs grundstruktur (jf. ovenfor), anses konstituentstrukturen i LFG for sprogspecifik og adskilt fra den grammatiske struktur, som antages at være en indre og universel struktur (Bresnan 2001: 45). Morfologi og topologi sidestilles således i LFG (Bresnan 2001: 6), hvorved det er muligt at beskrive både morfologiske og topologiske sprogs syntaktiske signifikation vha. LFGs træstruktur, idet det morfologiske sprog kan beskrives vha. en flad træstruktur (jf. Bresnan 2001: 8), mens det topologiske sprog kan beskrives ved den binære træstruktur som i den chomskyanske variant.

I LFG-modellen er a-strukturen den sproglige dimension til behandling af et leksikalsk elements betydning samt dets tematiske roller i en argumentstruktur:

\footnotetext{
An a-structure consists of a predicator with its argument roles, an ordering that represents the relative prominence of the roles, and a syntactic classification of each role indicated by a feature. (Bresnan 2001: 307)
}

Udgangspunktet for argumentstrukturen er således en 'prædikator' ("predicator"), og et af det verbale element krævet antal argumenter eller tematiske roller. Informationerne fra a-strukturen relateres derefter til fstrukturen gennem "mapping" (se evt. Kristensen 2004: kap. 3 for en nærmere beskrivelse).

I c-strukturen behandles den synlige konstituentstruktur, og formålet er at beskrive frasen og dens delelementer ved at placere disse hierarkisk eller relationelt (afhængigt af sprogtypen) i forhold til hinanden. Begrebet 'sætning' defineres ikke hos Bresnan, men om frasen fremhæves det:

Phrases are groups of contiguous words which are units for substitution, remain together as units under stylistic permutations and paraphrases of a sentence, contain the 
pronunciation patterns of sentences, and are subject to ordering constraint relative to other words and word groups. (Bresnan 2001: 5)

Denne definition bygger på den deskriptive grammatiks forståelse af frasen som en gruppe af 'ord', der kan gøres til genstand for substitution og permutation uden dermed at ophøre med at være en 'helhed' ("unit"), hvilket er en praktisk anvendelig men ikke en teoretisk tilfredsstillende definition, idet begreberne 'ord' og 'helhed' hverken her eller i andre teorier har fået teoretisk konsistente definitioner, ligesom fænomenet præpositionsstranding (prepositional stranding) om noget demonstrerer, at permutation ikke er et anvendeligt kriterium ved frasedefinitionen. Dermed står man tilbage uden klare grænser for frasen, idet man hverken kender start- eller slutpunktet for frasen. Man ved derfor, hvad man leder efter, men man ved ikke nødvendigvis, hvornår man har fundet det.

F-strukturen er den universelle sproglige dimension, hvori informationerne fra aog c-strukturen samles gennem "mapping"-proceduren og fortolkes i forhold til strukturens abstrakte grammatiske funktioner. F-strukturen hævdes at være en funktion i matematisk forstand (Bresnan 2001: 47), idet f-struktur opererer med en lukket mængde (sæt) af attributter og værdier, der kombineres til par. Det er dog for mig at se ikke helt klart, hvordan denne mapping-procedure egentlig foregår, og om f-strukturen virkelig er en funktion i matematisk forstand. Bresnan giver ingen klare definitioner af mapping-begrebet, så dér er der ingen hjælp at hente. En traditionel matematisk definition af mapping-begrebet kunne lyde som følger:

Term in mathematics for a function which associates each member of a set A with a member of another set B. The function is said to map into B; it maps A onto B if, in addition, there is no member of $B$ that is not associated with at least one member of A. (Matthews 1997: 217)

Ifølge den traditionelle matematiske definition, kan "mapping"-proceduren gå to veje mellem en definitionsmængde og en sekundærmængde (jf. Maesgaard, Prebensen og Vikner 1975: 63). Ved "mapping-into" forstås, at 'hvert medlem af en mængde A associeres med et medlem af en anden mængde B', dvs. alle medlemmer i A "kobles" sammen med et medlem i B, hvorved A som definitionsmængde er en afbildning ind i B som sekundærmængde (jf. 
Maesgaard, Prebensen og Vikner 1975: 60). Derved kan der forekomme medlemmer i B, som ikke er associeret med et medlem af A. Ved "mappingonto" eller den subjektive afbildning (jf. Maesgaard, Prebensen og Vikner 1975: 64) forstås derimod, at alle medlemmer af mængden B er associeret med 'mindst et medlem af $\mathrm{A}^{\prime}$, dvs. der må ikke være resterende medlemmer af mængden $\mathrm{B}$, når medlemmerne af $\mathrm{A}$ er afbildet på eller "onto" B. Størrelsen, som skal afstedkomme disse "mapping"-procedurer, kaldes en funktion - dvs. en funktion sikrer afbildningen af A i eller på B, eller en funktion associerer medlemmerne af A med medlemmerne af B på de omtalte måder.

Ifølge den matematiske definition skal "mapping"-proceduren finde sted med en funktion som "bindeled" mellem mængderne A og B, men denne funktion er svær at finde i LFG. F-strukturen skulle fungere som bindeled mellem a- og cstrukturen, men f-strukturen optræder tydeligvis selv som repræsentant for mængden B, idet informationerne fra a- og c-strukturen "mappes-into" og muligvis også “-onto" f-strukturen (jf. Bresnan 2001: 50 og 302), og dermed kan f-strukturen ikke også være funktionen, som afstedkommer "mapping"proceduren mellem mængderne A og B. Dertil kommer, at informationerne fra aog c-strukturen skal "mappes" til f-strukturen for yderligere behandling, hvilket også er utraditionelt i matematiske sammenhænge. Hvis f-strukturen faktisk skal være en funktion i matematisk forstand, så skulle "mapping"-proceduren som nævnt foregå mellem a- og c-strukturen, men i så fald ville det kun være muligt at påstå en "mapping-into"-procedure mellem A (a-strukturen) og B (cstrukturen), idet der i B ville forekomme en hel del informationer, som ikke vedrører A - herunder tempusforhold osv., der ikke kan "mappes-onto" astrukturens argumentstruktur. Det er imidlertid også muligt, at termen "mapping" ikke anvendes i traditionel matematisk forstand, men det er i så fald uklart i hvilken anden forstand, og jeg har ikke set nogen definition af begrebet i den LFG-litteratur, som jeg har beskæftiget mig med.

Jeg har således ikke tegnet fuldgyldigt medlemskab af hverken Chomskys eller Bresnans skoler, idet der i teoridannelserne er aspekter, der for mig at se får det respektive teoretiske grundlag til at vakle. For mig at se har både Bresnan og Chomsky endvidere det problem, at de teoretiske størrelser defineres internalistisk, hvorved der i de respektive teoridannelser ikke er størrelser, som peger ud af teorien, og dermed indlemmer virkeligheden i teoridannelsen - 
teoriernes forklaringer på de sproglige beskrivelser søges alene indenfor teoridannelserne selv. Bresnans og Chomskys interesser for universalgrammatikken og den medfødte sprogevne kan jeg dog til fulde tilslutte mig, tillige med det faktum, at de sproglige beskrivelser sættes ind i en formel teoretisk ramme.

\subsection{Delkonklusion}

Om man vælger en deskriptiv eller en formal teori som sit syntaktiske beskrivelsesapparat, får afgørende betydning for beskrivelsens udfald. Det deskriptive beskrivelsesapparats opgave er at benævne de syntaktiske størrelser, mens det ikke tilbyder en forklaringsramme for teoretiske spørgsmål vedrørende beskrivelserne. En formal teori nøjes ikke med at benævne de sproglige størrelser men tilbyder en teoretisk ramme, indenfor hvilken de sproglige beskrivelser kan forklares - forklaringer, der fx kunne vedrøre muligheden for sprogtilegnelse, sprogproduktion osv.

\section{SEMANTISKE ROLLER}

Traditionelt har de semantiske roller udgjort en art aktantmodel:

Der var en gang en helt (agent), som rejste (action) ud i verden, og dér besejrede han alle skurkene (patiens) ved hjælp af sin kløgt (instrument) og fik prinsessen og det halve kongerige (goal).

Forskellige teoretikere har opereret med forskellige termer for disse semantiske roller og til dels også forskellige definitioner heraf. Simon Dik arbejder fx med rollerne 'agent' og 'goal', der defineres:

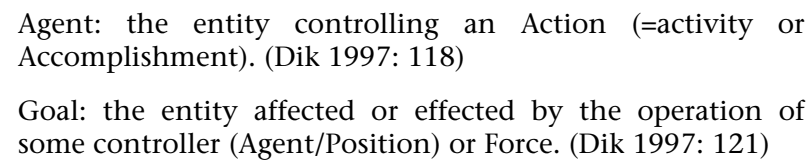

Hos Dik udgør begrebet 'agent' altså den handlende eller dén, der kontrollerer en handling, mens 'goal' markerer 'den, handlingen går ud over'. Fillmore arbejder derimod ikke med begrebet "goal" men med begreberne "agentive" og "objective": 
Agentive (A), the case of the typically animate perceived instigator of the action identified by the verb. (Fillmore 1968: 24)

Objective $(\mathrm{O})$, the semantically most neutral case, the case of anything representable by a noun whose role in the action or state identified by the verb is identified by the semantic interpretation of the verb itself; conceivably the concept should be limited to things which are affected by the action or state identified by the verb. The term is not to be confused with the notion of direct object, nor with the name of the surface synonymous with accusative. (Fillmore 1968: 25)

Fillmore er i modsætning til den deskriptive grammatiks definitioner af subjektet og objektet (jf. ovenfor) ikke umiddelbart klar til at sammenkæde "objective" med sætningens objekt, men derimod sammenkæder han gerne "agentive" såfremt en sådan rolle forekommer i en sætning - med sætningens subjekt:

If there is an A, it becomes the subject; otherwise, if there is an I[nstrument], it becomes the subject; otherwise, the subject is the O. (Fillmore 1968: 33)

Uanset at teoretikerne anvender forskellige betegnelser, er tendensen dog den samme: man antager, at konstituenterne spiller roller i det scenarium, som sætningen udtrykker. Problemet med de semantiske roller er, at man som teoretiker nødvendigvis må forstå sætningen, før man kan analysere sig frem til, hvilke af sætningens størrelser, der udgør hvilke semantiske roller - der gives ingen kriterier, der ligger ud over scenariet, for udpegelse af de semantiske roller, og derfor står en analytiker, som ikke har meldt sig ind i det teoretiske fællesskab, uden for.

Hvis jeg har forstået den tidlige Fillmore ret, opererer han ikke med en overordnet sprogteori, hvorved han forsøger at forklare fx sprogtilegnelse, sprogproduktion osv. Godt nok gør han sig tanker om bl.a. sprogtypologisk klassificering baseret på de semantiske roller samt relationen mellem de semantiske roller og kasus i traditionel forstand, men intet synes at pege ud over aktantmodellen og den deskriptive tilgang. Derfor er det for mig at se svært at afgøre, hvad Fillmore egentlig vil med sin teoretisering - vil han blot beskrive sproglige konstruktioner (hvilket for mig at se er uinteressant uden en sprogteori), eller har han andre, skjulte mål, som endnu ikke er blevet præsenteret i en generel sprogteori? 


\title{
SUSANNE ANNIKKI KRISTENSEN
}

Dertil kommer, at der i de forskellige teorier om semantiske roller er en klar tendens til at gribe til ad hoc-løsninger, når de eksisterende semantiske roller ikke er anvendelige til beskrivelse af en given konstruktion. Dette demonstreres med al tydelighed af fx Whaley:

\begin{abstract}
If just the semantic properties of volition, force, and control are considered, one might take agent in the most restrictive sense as a nominal that possesses all three of these properties. The nominal Mary in "Mary angrily rolled the ball down the hill" would be an agent because it describes a entity who chose to roll the ball (i.e., had the property of volition) and caused the rolling (i.e. has the property of force). On the other hand, in the sentence, "Mary rolled the ball by mistake," the nominal Mary could no longer be called an agent because it does not refer to an individual that is acting volitionally. If one followed this tack, then a different semantic role would need to be posited for Mary. One might use the label effector, for example. (Whaley 1997: 66)
\end{abstract}

Ad hoc-løsninger giver et klart deskriptivistisk præg, idet nye størrelser blot inkorporeres i systemet, når det viser sig nødvendigt, uden at disse nye termer nødvendigvis hænger sammen med resten af nomenklaturen. Når dette kritikpunkt kobles sammen med den manglende integrering af de semantiske roller i en overordnet sprogteori, kommer teorien til at bære præg af at være benævnende frem for forklarende, og det er for mig at se uinteressant.

Spørgsmålet er desuden, om de semantiske roller er nødvendige for den sproglige beskrivelse - om man kan foretage adækvate sproglige beskrivelser uden brug af semantiske roller? Hvis alternativet er deskriptiv grammatik eller formelle beskrivelser på vaklende teoretisk grund (jf. ovenfor), så er beskrivelsen af de semantiske roller givetvis nødvendig for en forståelse af en sætnings semantik. Selv mener jeg ikke, at det er nødvendigt at operere med sådanne størrelser, hvis man ellers arbejder med en konsistent syntaktisk teori (jf. nedenfor for et forslag til en sådan).

\subsection{Delkonklusion}

Teoretikere, der arbejder med semantiske roller, er ofte ikke enige om valg af termer samt definitioner heraf. Man synes dog enige om at betragte sætningen som en art scenarium, hvor der indgår en række aktanter eller roller. Som oftest defineres disse roller internalistisk, idet scenariet alene er definitionens ramme, 
og dermed er der klare lighedspunkter i definitionsmåderne hos fx Chomsky og Fillmore. Jeg finder grundlæggende de internalistiske definitioner problematiske og ser hellere termerne eksternalistisk defineret (jf. nedenfor).

\section{SAMMENFATNING}

I det foregående har jeg behandlet det traditionelle syn på henholdsvis kasus, sætningsled og semantiske roller. Som det fremgik af afsnittet om kasus, fandt jeg det betænkeligt at tage udgangspunkt i morfologi frem for syntaks ved beskrivelsen af naturligt sprog, især hvis der samtidig antages at være en-til-enkorrespondance mellem form og funktion. Jeg ser hellere den sproglige beskrivelse begyndt med en syntaktisk beskrivelse (jf. nedenfor). Ligeledes fandt jeg bestræbelserne på at finde universalier og universelle betydninger i kasussystemerne uhensigtsmæssig, især når et specifikt sprogs kasussystem bliver sat som norm for at andet sprogs kasussystem. Jeg ville ligeledes foretrække, at begrebet kasus anvendes om morfologisk udtrykte former, idet det så er muligt at skelne mellem forskellige måder at angive syntaktisk signifikation, frem for at tale om usynlige kasus, der for mig at se udvander begrebet.

I afsnittet om sætningsled afviste jeg i tilslutning til Chomsky den deskriptive tilgang som uinteressant, idet de sproglige beskrivelser ikke sættes ind i en teoretisk ramme, som kan forklare de sproglige iagttagelser. Jeg afviste dog også delvist Chomskys generativisme pga. den stærke fokusering på ledfølge samt krav om accept af både synlige og usynlige flytninger. Desuden fandt jeg det problematisk at betragte kasus som en defekt ved sprog - kasus spiller en rolle på lige fod med topologi. Jeg afviste desuden LFG dels pga. frasedefinitionen, der var pædagogisk men ikke teoretisk tilfredsstillende, og dels pga. mappingbegrebet, der er behæftet med nogen uklarhed. Desuden fandt jeg det problematisk, at både Chomsky og Bresnan definerer de tekniske termer internalistisk, idet virkeligheden så svært finder vej til teorien. Derimod tilslutter jeg mig både Chomskys og Bresnans mål om at formulere en teori om sprogevnen.

I afsnittet om de semantiske roller fandt jeg det problematisk, at der som oftest ikke arbejdes med en overordnet sprogteori, hvori de semantiske roller kan indgå, og hvor beskrivelsen af de semantiske roller kunne be- eller afkræfte den overordnede teori. Når de semantiske roller desuden oftest er internalistisk 
defineret, kan forklaringen på sproglige beskrivelser kun søges i den interne teori. Jeg fandt det også problematisk, at man ofte må ty til ad hoc-løsninger ved sproglige beskrivelser - dette vidner ikke om en konsistent teori. Dertil kommer, at jeg ikke er overbevist om, at det er nødvendigt at operere med semantiske roller ved en adækvat sproglig beskrivelse - jeg mener ikke, at de semantiske roller tilfører noget væsentligt til beskrivelsen, især ikke hvis målet er at beskrive sprogbrugerens sprogproduktion og forhold til virkeligheden.

Jeg vil derfor foreslå en alternativ analyseprocedure, hvor den syntaktiske beskrivelse - baseret på en formal teori - går forud for den morfologiske beskrivelse, hvor intet er usynligt, og hvor de semantiske aktanter har udspillet deres roller.

\section{EN ALTERNATIV TILGANG TIL SPROGBESKRIVELSER}

I de følgende afsnit vil jeg på baggrund af min tidligere kritik plædere for følgende: (1) De semantiske roller er unødvendige i den sproglige beskrivelse, (2) kasus er hverken usynlige eller en defekt ved sprog og (3) den sproglige beskrivelse bør begynde med en syntaktisk beskrivelse.

\subsection{Semantiske roller er unødvendige i den sproglige beskrivelse}

Mit eget teoretiske ståsted er den såkaldte Epi-Formale Syntaksteori (herefter EFA(X)), oprindeligt udviklet af Hans Götzsche (1994) og siden revideret (jf. Kristensen 2001 og 2004).

EFA(X) bygger grundlæggende på en række generelle, ontologiske påstande: der eksisterer noget sådant i det menneskelige kognitive system, som kan kaldes henholdsvis et grammatisk, et semantisk og et pragmatisk modul, og disse moduler samarbejder ved produktionen og fortolkningen af sprog. Når modulerne aktiveres, udløses en sprog-processering, hvis produkt (i form af sproglige lyde eller skrift) er specifikt for en gruppe af sprogbrugere, der taler eller skriver samme modersmål.

Desuden bygger $\mathrm{EFA}(\mathrm{X})$ på en række universelle, teoretiske påstande: det er muligt at formulere et formalt system til beskrivelse af natursproglig syntaks, og systemet dannes af formalt definerede termer, hvoraf én er termen SUBJEKT. På baggrund af det formale system er det muligt at lave strukturelle beskrivelser 
(dvs. klassificeringer af de sproglige elementer), der eksemplificerer mulige kombinationer af de teoretiske termer.

I EFA(X) hænger sprogproduktion samt sprogbrugerens forhold til verden nøje sammen med det tredelte tegnbegreb bestående af 'udtryk' ("expression"), 'fremsættelse' ("exposition") og 'indhold' ("content"). Til trods for at EFA(X)tegnbegrebets størrelser 'udtryk' og 'fremsættelse' til en vis grad svarer til Saussures (1916) begreber "Image acoustique" og "Concept" (jf. Götzsche 2005a: $10)$, er der dog en afgørende forskel mellem de to tegnbegreber, nemlig at EFA(X)-tegnbegrebet udgøres af en hel sætning (i ikke-teknisk forstand), mens Saussures tegnbegreb udgøres af enkelte ord (uden at han definerer begrebet 'ord' teoretisk). Tegnbegrebet i $\mathrm{EFA}(\mathrm{X})$ ser ud som følger: 
Linguistic material structures (media): sounds and writings

MEDIUM ASSIGNMENT: the mental and material processes of producing

(creating or utilizing) articulation and writing

।

Mental images from perception (representations) and cognition

\begin{tabular}{|c|c|c|c|}
\hline (discourse: & structures & constructions & \\
\hline utterance & language & sign & minimal sign) \\
\hline expression(s) & form (gramma-*) & style & $\begin{array}{l}\text { sentence (of } \\
\text { constituents) }\end{array}$ \\
\hline |** & & & \\
\hline expositions(s) & sense $\left(\right.$ sema- $\left.^{*}\right)$ & logic & statement (of concepts) \\
\hline$\left.\right|^{* *}$ & & & \\
\hline content(s) & meaning (pragma- ${ }^{\star}$ ) & information & $\begin{array}{l}\text { stratification (of } \\
\text { configurations) }\end{array}$ \\
\hline
\end{tabular}

mental images from perception (representations) and cognition

।

OBJECT ASSIGNMENT: the processes of activating (creating or actualising) one or more concepts (of mental objects or (as mental representations of) material objects) - so that they are part of the conscious mental universe - connected (as reference) with related interactions with the world

।

material structures: the world

** mental structures of SIGNIFICATION

* structures

(Götzsche 2005a: 11-12) 
Indholdsstørrelsen i tegnbegrebet repræsenterer en art grænseflade mellem det sproglige tegn og verdens genstande, ligesom udtryksstørrelsen repræsenterer en grænseflade mellem det sproglige tegn og den faktiske, materielle lyd. I OBJECT ASSIGNMENT sker en kobling mellem mentale billeder af (de af sprogbrugeren perciperede) genstande i verden og de mentale billeder af de til genstandene knyttede sproglyde. Når denne kobling finder sted, opstår et mentalt sprogligt tegn, der siden kan produceres som faktiske sproglige lyde i en kommunikation. Ligeledes sker der i MEDIUM ASSIGNMENT en kobling mellem sprogbrugerens mentale billeder af sproglige lyde og nogle for den specifikke sprogbruger særegne aktualiserede mentale billeder af genstande i virkeligheden, og når denne kobling finder sted, opstår eller aktualiseres et mentalt sprogligt tegn. På den måde kan dannelsen af et mentalt sprogligt tegn gå to veje - enten ved at sprogbrugeren perciperer genstande i virkeligheden, eller ved at sprogbrugeren perciperer lyde i virkeligheden (og genkender disse som sproglige lyde). Hvis fx de mentale billeder af genstande i verden ikke kobles sammen med mentale billeder af de dertil knyttede sproglyde, opstår der intet mentalt tegnbegreb, men der er blot tale om stratifikationer; det er det, der sker, når en sprogbruger tænker, fantaserer eller dét, der i folkemunde betragtes som ikke at kunne komme i tanke om et ord.

Tegnbegrebets tre interne størrelser, udtryk, fremsættelse og indhold tænkes desuden at samarbejde med tre mentale moduler, der udgør sprogbrugerens sprogevne:

\footnotetext{
I assume that the core of the MENTAL LANGUAGE FACULTY is a STRUCTURE of COGNITIVE SYSTEMS incorporating three 'moduls' (or three collaborating cognitive subsystems):

a SEMANTIC MODULE operating the structures of the LEXICON, i.e. a part of memory in which linguistic expressions (the (mental images of) morphemes constructed as sequences of phonemes) are connected with linguistic contents (the image of) mental or material objects) thereby structuring concepts; by means of the grammatical and pragmatic modules concepts can be created (and accumulated in the lexicon) or actualised (from the lexicon) in constructions of constituents in sentences and as concepts in statements,

a GRAMMATICAL MODULE operating the processes of syntax, i.e. the processes of generating and interpreting constructions of expressions (constituents in sentences), causing the memorising or materialisation of phones and/or graphs,
} 
a PRAGMATIC MODULE operating the processes of attention, i.e. the processes of generating and interpreting constructions of content (configurations in stratifications), causing the memorising or materialisation of perception of objects. (Götzsche 2005a: 73)

I det semantiske modul lagres begreber, og det er det grammatiske og det pragmatiske moduls opgave at aktualisere begreberne - dvs. "hente" begreberne ud af leksikonet ved sprogproduktionen, idet det grammatiske modul henter mentale billeder af det sproglige tegns udtryk (form), mens det pragmatiske modul henter mentale billeder af tegnets indhold (betydning). Kombinationen af de mentale billeder af det sproglige tegns udtryk og indhold finder således sted i det semantiske moduls begreber, hvorfor det semantiske modul ligesom det sproglige tegns fremsættelse kan karakteriseres som et krydsfelt mellem de sproglige tegns udtryk og indhold. Når begreberne aktualiseres, sættes de i relation til hinanden, hvorved 'udsagn' ("statement") dannes, og et udsagn består da af en struktur af mentale udtryks- og indholdsbilleder. Et UDSAGN og dets delelementer kan derefter defineres formelt:

\begin{abstract}
the standard "form" of a statement (STM) is a structure (forms as functions) of concepts (CPTs) (Götzsche 2005b: 1)

SUBJECT [Symbol: $S$ ]: the concept which is (in a situation) the mental object (ie a configuration) of the (act of linguistic communication (ie transfer of information) of the) interlocutor uttering the statement
\end{abstract}

VERBATE [Symbol: V]: the concept which *subjects and/or ${ }^{*}$ conjects the subject

OBJECT (or *SPECIFICATE) [Symbol: O]: the concept which is an assertive specification of the subject by *conjection

PREDICATE [Symbol: P]: the concept which is a predication of the subject by *conjection

CONJUNCTION [Symbol: C]: the concept which may connect different statements or, within a statement, concepts of the same category, or concepts related by comparison. (Götzsche 2005b: 1)

*ADVERBATE: the CPT which is a predication of the VERBATE (Kristensen 2004: 121)

Relationerne mellem SUBJEKTET og de resterende begreber defineres:

*subjection: assertive (a-)specification, or predication

a-specification: the CPT subclassifies another CPT [cf stipulative (s-)specification: a subclassified CPT] 
predication: the CPT (re-)classifies another CPT

*conjection: a relation between two CPTs by a third CPT

*verbation: the *subjection or * ${ }^{*}$ conjection which constitutes a STM

equation: predication by class identification

comparison: predication by class intersection

negation: a-specification or predication by complementary classification. (Götzsche 2005b: 1)

Udsagnet og begreberne er som nævnt ikke direkte observerbare, mentale størrelser, og de kan derfor kun behandles indirekte, når de er blevet manifesteret enten lydligt eller grafisk gennem sætninger og konstituenter:
a sentence is (generated as) the form [cf ling sign] of a statement, ie the constituents are (generated as) the forms of the concepts;
The standard "form" of a sentence (STC) is a structure of constituents (CSTs); the structural functions of the constituents are syntactic functions establishing CST- categories containing categorical units:
(5) conjunctional, (1) subject, (2) verbal,
object/predicative, (4) adverbial. (Götzsche 2005b: 2-3)
subject [Symbol: $s]$ form of the SUBJECT of the statement
verbal [Symbol: $v$ ] form of the *VERBATE of the STM
object [Symbol: $o$ ] form of the OBJECT of the STM
predicative [Symbol: $p$ ] form of the PREDICATE of the STM
conjunctional [Symbol: c]: form of the CONJUNCTION of the STM (Götzsche 2005a: 3)
adverbial [Symbol: a]: form of the *ADVERBATE of the STM (Kristensen 2004: 121)

Om der i en sætning forekommer en given konstituent afhænger af, om der i udsagnet optræder det tilsvarende begreb, idet begreberne anses for at generere konstituenterne (Götzsche 2005a: 34).

Efter denne lidt tekniske og meget opsummerende gennemgang af grundtankerne i $\mathrm{EFA}(\mathrm{X})$ vil det være på sin plads med et par kommentarer om, hvordan sprogproduktionen tænkes at foregå. Man kan tænke sig en situation, hvor en sprogbruger observerer en flaske på et sofabord. Idet sprogbrugerens perception finder sted, etableres mentale billeder af de to genstande samt relationen mellem dem hos sprogbrugeren, og samtidig kobles disse mentale 
billeder sammen med mentale billeder af de til genstandene forbundne sproglyde (forudsat at disse kendes af sprogbrugeren). Koblingen mellem de mentale billeder og genstandene i verden finder sted i den såkaldte 'genstandens tegnsliggørelse' ("OBJECT ASSIGNMENT") i tegnbegrebet, og når koblingen finder sted, opstår et mentalt sprogligt tegn. Hvis sprogbrugerens perception gælder sproglige lyde i verden foregår der på samme måde en kobling mellem de mentale udtryks- og indholdsbilleder, men koblingen finder dog sted i 'udtryksmidlets tegnsliggørelse' ("MEDIUM ASSIGNMENT"). De mentale udtryks- og indholdsbilleder, som er blevet etableret på grundlag af sprogbrugerens perception, udgør siden et UDSAGN bestående af en begrebsstruktur, og ét af disse begreber bliver UDSAGNETS fikspunkt eller SUBJEKT, der defineres som 'begrebet, der er det mentale objekt for sprogbrugeren, som ytrer udsagnet i en kommunikationssituation'. De øvrige begreber forholder sig alle direkte eller indirekte til SUBJEKTET. UDSAGNET kan derefter manifesteres lydligt eller grafisk gennem en sætning bestående af en konstituentstruktur. Hvordan denne faktiske lydproduktion foregår, er endnu ikke klarlagt inden for teorien.

Ud fra denne tanke om sprogproduktion er det for mig at se ikke nødvendigt at arbejde med semantiske roller. I min optik forholder det sig sådan, at virkeligheden eksisterer, at der er materielle genstande $\mathrm{i}$ den, og at disse genstande indgår $\mathrm{i}$ en eller anden relation med hinanden. Sprogbrugeren genskaber derefter verden mentalt ved dannelsen af de mentale begreber, og sprogbrugeren forholder sig siden hen til verden ved at sætte et af begreberne (dvs. SUBJEKTET) som fikspunkt for sit UDSAGN - derved markerer sprogbrugeren, hvad der ligger indenfor sprogbrugerens interesse- og vidensfelt. UDSAGNETS øvrige begreber forholder sig derefter til fikspunktet - i folkelingvistiske termer kan det siges, at de øvrige begreber "siger noget om" subjektet, hvilket er helt i tråd med den klassiske logik.

Noget andet er, at begrebet SUBJEKT defineres direkte eksternalistisk, mens de resterende begreber alle defineres ved deres relation til SUBJEKTET og derfor må betegnes som indirekte eksternalistisk definerede. Dermed adskiller EFA(X) sig for mig at se fra andre formelle og generative teorier, som definerer de tekniske termer internalistisk; fordelen ved de eksternalistisk definerede termer er dels, at man kan tilgodese, at sprog (også) bruges af en sprogbruger til kommunikation, 
og dels, at det undgås, at teorien bliver et lukket system uden forbindelse til virkeligheden, hvor forklaringen på et sprogligt fænomen kun kan søges i det lukkede system, som det i nogen grad er tilfældet hos Chomsky, Fillmore og til dels hos Bresnan (jf. tidligere). Ved internalistiske definitioner er der således ingen adgang for virkeligheden og sprogbrugeren, men ved de eksternalistiske definitioner vil teorien altid pege ud på virkelighedens størrelser, ligesom det er muligt at finde eksterne forklaringer på de sproglige beskrivelser.

\subsection{Kasus er hverken usynlige eller en defekt ved sprog}

Ligesom i LFG sidestilles morfologi og topologi i EFA(X), idet begge antages at være mekanismer til angivelse af syntaktisk signifikation (jf. Götzsche 1994: 75). Begrebet 'syntaktisk signifikation' bruges om mekanismen til udpegelsen af et givent sætningselement som konstituent i en sætningsstruktur - dvs. det udpeger et sprogligt elements funktion i en syntaktisk struktur (jf. Götzsche 2005a: 35); denne signifikation kan foregå topologisk eller morfologisk (eller eventuelt via toner i tonesprog), idet enten ledfølge eller morfologi kan være betegnende for en bestemt konstituenttype. I dansk er der som bekendt kun et rudimentært kasussystem, og derfor bruges topologien til at afgøre et sprogligt elements funktion i sætningen; et subjekt kan derfor kendes på, at det kan placeres enten som første led i en ikke-sidestillet helsætning (i Fundamentet i Diderichsens sætningsskema (1946)) eller lige efter det finitte verbal (dvs. på spladsen i sætningsskemaet). I finsk er der som nævnt fleksibel ledfølge, hvilket skyldes det rigt udbyggede kasussystem, der sikrer, at den syntaktiske signifikation foregår morfologisk i finsk. Sprog som tyrkisk og tysk er interessante, fordi der både er et udbygget kasussystem til angivelse af den syntaktiske signifikation ad morfologisk vej, men der er samtidig en relativ rigid ledfølge, der ligeledes kan angive den syntaktiske signifikation ad topologisk vej (jf. Kristensen 2001). Årsagen til denne dobbelte signifikation kræver nærmere studier.

I henhold til antagelsen om kasus som en mekanisme til syntaktisk signifikation, giver det ikke mening at tale om usynlige kasus, som Fillmore gør det, eller om kasus som en defekt ved sprog, som Chomsky gør det. Kasus er for mig at se alene et spørgsmål om morfologisk form, mens sprog som ikke udtrykker synlige kasus, lader den syntaktiske signifikation foregå ad anden vej. 
En konsekvens af dette syn på kasus er også, at kasussystemer for mig at se ikke kan være universelle, når kasus som sådan er en sprogspecifik mekanisme; at der tilsyneladende er sammenfald af visse kasusanvendelser i de forskellige specifikke sprog, skyldes i nogen grad konventioner - man har fx vedtaget, at nominativ (i ikke-ergative sprog) anvendes ved subjekter (og at subjekter udtrykker nominativ!), men i sprog som fx finsk kan det adessive lokalkasus både anvendes til angivelse af et subjekt og et adverbielt led:

(2) Auto

Bil (nomv)

$\mathrm{S}$

'Bilen er på gaden'.

ligesom det kan angive et subjekt:

(3) Minu-lla

Jeg-adev

'Jeg har en bil.' kadu-lla

gade-adev

\section{være-3.sing.pres.indv}

v 
manglende kongruens mellem subjektet og verbalet kan da forklares ved, at der er tale om en formel i den Jespersenske (1924) forstand, således at harkonstruktioner i finsk dannes ved en forbindelse af on + adessiv samt et objekt, og med den fikserede ledfølge på trods af en ellers fleksibel ledfølge i de finske konstruktioner. Derfor kan adessiven for mig at se også være syntaktisk betegnende for finske subjekter i disse særlige typer af konstruktioner, og dermed er der grund til at anse adessivens brug for sprogspecifik for finsk, selvom man også kan finde adessiven anvendt $\mathrm{i}$ andre sprog.

\subsection{Den sproglige beskrivelse bør begynde med en syntaktisk beskrivelse}

Det bør nu stå klart, at jeg med $\operatorname{EFA}(\mathrm{X})$ i hånden på mange punkter tilbyder alternative definitioner og løsninger på beskrivelser af sproglige problemer. Derfor også et alternativt syn på hvorledes den sproglige beskrivelse bør foregå og hvilke forklaringer, der er adækvate.

Som nævnt sidestilles kasus og topologi i $\mathrm{EFA}(\mathrm{X})$ pga. deres identiske funktion som mekanismer til syntaktisk signifikation - dvs. deres funktion som syntaktisk betegnende er universel, men manifestationen i faktiske sproglige former er partikulær eller sprogspecifik. I modsætning hertil er syntaksen - dvs. begreberne og konstituenterne, deres definitioner og indbyrdes forekomstrelationer (jf. Götzsche 2005a: 36) - universel, idet disse har baggrund i den universelle teori.

På denne baggrund foreslår jeg, at den sproglige beskrivelse tager udgangspunkt i syntaksen frem for i morfologien, som traditionen ellers ofte tilsiger. For mig at se kommer der mere adækvate beskrivelser ud af at gå fra det generelle til det specifikke eller fra det universelle til det partikulære frem for omvendt. Der er for stor fare for at lave overgeneraliseringer, hvis man bevæger sig fra det sprogspecifikke for derigennem at forsøge at finde generelle egenskaber ved sprog.

En adækvat sproglig beskrivelse er derfor for mig at se en formal beskrivelse af en konstruktionen, og denne formale sproglige beskrivelse tager sin begyndelse i en annotering af sætningens konstituenter foretaget på baggrund af de eksternalistisk definerede konstituenter. Dernæst annoteres frasens elementer, som jeg kalder komponenter (jf. Kristensen 2004), ligesom de eventuelle morfologiske informationer i frasen klarlægges. Denne beskrivelse er ikke formal, 
idet der blot er tale om en kategorisering af konstruktionens delelementer. Den formale beskrivelse kommer først i stand, når den strukturelle beskrivelse gennemløber en formal kalkule for det specifikke sprog. Hvis den strukturelle beskrivelse ikke divergerer $\mathrm{i}$ forhold til den formale kalkule, betragtes den formale beskrivelse som succesfuld.

Til demonstration af proceduren og $\mathrm{EFA}(\mathrm{X})$-tegnbegrebet tages udgangspunkt $\mathrm{i}$ beskrivelsen af følgende tvetydige konstruktion:

Peter fik formodentlig en hund.

I konstruktionen består det tvetydige i indholdet af størrelsen 'hund', idet udtrykket kan bruges om enten et levende væsen med visse distinkte karakteristika eller om en pengeseddel af værdien 100 kroner. Teorierne om de semantiske roller vil ikke kunne redegøre for forskellen mellem de to betydninger, endsige udpege, at der er tale om mentale billeder af to forskellige genstande i virkeligheden. Der vil ved begge betydninger blot være tale om 'goal', 'objective' eller 'patiens' afhængig af terminologivalg.

I EFA(X) foregår afklaringen af begrebet 'hund's betydning i den mentale, pragmatiske struktur, og metoden til afgørelse af betydningen er konteksten. Uden en kontekst ville tvetydigheden ikke kunne gøres entydig. I den pragmatiske struktur afklares betydningen, og sprogbrugerens mentale billeder af virkelighedens genstande kan kobles sammen med sprogbrugerens mentale billeder af de dertil forbundne lyde, hvorved tegnbegrebet opstår og kan gøres til genstand for lydlig manifestation i en sætning.

Sætningen analyseres efterfølgende ved først at annotere konstituenterne:

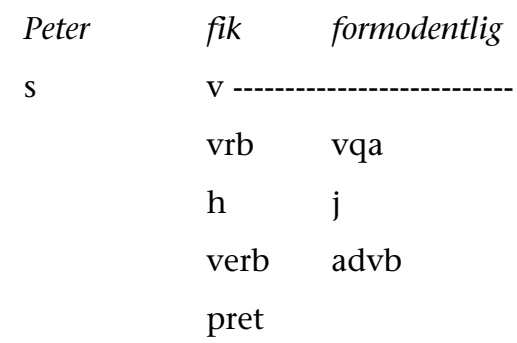


I første analyselinje noteres konstituenterne, og utraditionelt i den forbindelse er det at analysere formodentlig som en del af verbalfrasen. Denne analyse fremkommer dog som en følge af mit syn på forskellen mellem adverbier og adverbialer (jf. Kristensen 2004: 119ff.), hvor adverbialerne anses for "selvstændige" konstituenter, som prædikerer verbalet (jf. Kristensen 2004), mens adverbierne betragtes som specificerende komponenter i en verbalfrase, dvs. som adled til beskrivelse af verbalet. I ovenstående tilfælde fungerer adverbiet som en vqa-komponent, dvs. som et verbalt kvasiadverbium med følgende definition:

Specification by presupposition. (Kristensen 2004: 125)

Den kvasiadverbielle komponent er dét, der i den traditionelle grammatik ofte betegnes som sætningsadverbialer, der ligeledes traditionelt antages at modificere hele sætningens indhold (jf. f.eks. Crystal 1980 (1997): 11 og Matthews 1997: 338). Jeg kan tilslutte mig, at de kvasiadverbielle udtryk er sætningsadverbialer, men i $\mathrm{EFA}(\mathrm{X})$ bruges begrebet sætningsadverbial dog i en lidt anden betydning. I $\operatorname{EFA}(\mathrm{X})$ betragtes de kvasiadverbielle elementer som sætningssubstitutioner med en præsuppositionel funktion (Götzsche 1998: 147); heraf betegnelsen kvasiadverbial. I forhold til den omtalte konstruktion kunne man således sige, at formodentlig substituerer sætningen der er grund til at tro + at Peter fik en hund, hvorved vqa-komponenten ikke modificerer sætningen, som den indgår $\mathrm{i}$, sådan som traditionen foreskriver, men vqa substituerer derimod en "anden" sætning.

Begrundelsen for at betragte det kvasiadverbielle element (tillige med andre specificerende adverbier, jf. Kristensen 2004: 119ff.) som en del af verbalfrasen og ikke som et selvstændigt adverbielt led er, at der i morfologiske sprog er en tendens til at udtrykke disse adverbielle informationer som derivationelle informationer i verbalet. I grønlandsk forekommer fx derivationen -qqooqaaqmed betydningen 'vist nok' (Olsen og Hertling 1988: 62) som en verbalderivation. I topologiske sprog som fx dansk synes der også at være flere topologiske restriktioner på de specificerende adverbielle udtryk end på de "selvstændige" adverbialer. De specificerende adverbielle udtryk placeres oftest tættere på verbalet og med færre placeringsmuligheder end de selvstændige adverbialer - specificerende adverbielle komponenter kan således kun placeres på 
F- og a-pladsen i Diderichsens sætningsskema, mens adverbialerne kan placeres på en hvilken som helst adverbiel plads i skemaet.

I anden analyselinje noteres frasens komponenter, og ud over vqa-komponenten optræder der her også en det-komponent - dvs. en "determiner" eller en bestemmer, hvis definition adskiller sig fra den traditionelle grammatiks:

Specification of referential in/determinacy. (Kristensen 2004: 124)

Traditionelt har bestemmere været en broget gruppe af sproglige størrelser, der har kunnet repræsentere både bestemmere som artikler, demonstrativer og possessiver samt kvantorer (Trask 1993: 80), hvis fællestræk udelukkende har været af distributiv karakter ved deres placering i såkaldte 'artikelpositioner' (Crystal 1980 (1997): 112). Jeg karakteriserer derimod bestemmeren som angiver af referentiel ( $\mathrm{u}$ )afgørbarhed - dvs. bestemmeren angiver om referenten er afgørbar eller ikke-afgørbar eller med andre ord, om referenten kan udpeges. I den aktuelle sætningskonstruktion kan referenten derfor ikke udpeges qua ubestemtheden.

I analysens tredje linje angives komponentrelationerne. I EFA(X) som i den traditionelle grammatik er det muligt i en frase af have ét og kun ét habitat (dvs. kerne) med symbolet $\mathrm{h}$ og et $\mathrm{i}$ princippet uendeligt antal indekser (dvs. adled/attributter) med symbolerne j eller $\mathrm{g} .{ }^{6}$

I den fjerde analyselinje angives frasekomponenternes ordklasser (som endnu ikke er blevet defineret formelt i $\operatorname{EFA}(X)$, men definitionerne er på vej), og i de efterfølgende analyselinjer angives eventuelle morfologiske informationer - dvs. morfologiske informationer af sprogspecifik karakter.

Efter annotationen af sætningens konstituenter og komponenter skal de strukturelle beskrivelser gennemløbe den opstillede formale kalkule for dansk, og hvis den strukturelle beskrivelse ikke divergerer i forhold til kalkulen, er der tale om en succesfuld formal beskrivelse. Artiklens pladsbegrænsning tillader imidlertid ikke en præsentation af og en forklaring på den formale kalkule for dansk, men jeg kan henvise til Kristensen (2004) for en nærmere redegørelse. 
Analysen vha. $\operatorname{EFA}(\mathrm{X})$ går på den måde fra det generelle til det sprogspecifikke, fra syntaks til morfologi. Eftersom konstituenterne i EFA(X) korresponderer med de omtalte begreber, kan den strukturelle beskrivelse vha. $\operatorname{EFA}(\mathrm{X})$ siges at være en genkendelse af de grammatiske, semantiske og pragmatiske informationer i begrebsstrukturen. Derfor beskrives begrebsstrukturen indirekte ved beskrivelsen af den syntaktiske struktur i et sprog, og derfor kan beskrivelsen af det specifikke sprog bruges til at be- eller afkræfte tesen om begrebsstrukturen - dens elementer og deres indbyrdes relationer - og i sidste ende tesen om tegnbegrebet i EFA(X). Derfor er de sproglige beskrivelser foretaget med baggrund i EFA(X) interessante.

\section{KONKLUSION}

I det foregående har jeg plæderet for et nyt syn og en ny procedure ved sproglige beskrivelser. Den traditionelle grammatiks syn på kasus og morfologi som udgangspunktet for sproglige beskrivelser blev behandlet og forestået erstattet med et syn, der sætter syntaksen over morfologien. Ifølge dette syn på grammatik kan morfologi betragtes som en sprogspecifik mekanisme til angivelse af syntaktisk signifikation, mens den syntaktiske struktur manifesterer den universelle begrebsstruktur, og eftersom den sproglige beskrivelse bør tage udgangspunkt i det generelle frem for det specifikke for at undgå overgeneraliseringer, bør den sproglige beskrivelse tage udgangspunkt i syntaksen og dernæst behandle morfologien. Kasus og kasussystemer kan ifølge dette alternative syn heller ikke være hverken universelle eller usynlige qua den teoretiske antagelse, at kasus er en sprogspecifik mekanisme til syntaktisk signifikation.

Jeg plæderede ligeledes for, at Chomskys og Bresnans respektive teorier bør afvises; Chomskys teori bl.a. pga. synet på kasus som en defekt ved sprog, og Bresnans bl.a. pga. de uklare frase- og mappingbegreber. Hos Chomsky er det endvidere nødvendigt at arbejde med flytninger, men ved både LFG og $\operatorname{EFA}(\mathrm{X})$ undgås flytningerne, i LFG pga. synet på den syntaktiske struktur som sprogspecifik, og i $\operatorname{EFA}(\mathrm{X})$, fordi de specifikke formelle kalkuler formuleres på baggrund af sprogspecifikke forhold.

En grund til at afvise både Chomskys, Bresnans og Fillmores teorier var desuden, at alle disse teorier definerede de indgånde termer internalistisk, hvilket medfører, at forklaringer på de sproglige beskrivelser skal findes internt i 
teorierne, mens virkeligheden og sprogbrugeren var forment adgang. Dette problem kan løses ved at definere de tekniske termer eksternalistisk og gerne vha. pragmatikken, hvorved det tilgodeses, at sprog bruges af nogen til at kommunikere noget til nogle andre.

Sidst men ikke mindst plæderede jeg for, at de semantiske roller ikke er nødvendige i beskrivelsen af sproglige konstruktioner, og dette demonstrerede jeg dels ved analysen af et tvetydigt sætningseksempel, som teorierne om de semantiske roller ikke ville kunne beskrive eller forklare, og dels ved inddragelse af det tredelte tegnbegreb som involverede virkeligheden, sprogbrugerens syn herpå og de deraf følgende mentale begreber. Med det tredelte tegnbegreb samt relationerne mellem begrebsstrukturens elementer er det ikke nødvendigt at operere med udelukkende sætningsinterne størrelser som de semantiske begreber. Derfor har aktanterne udspillet deres roller.

Den oprindelige titel for lingvistkollokviet på Statsbiblioteket (2006) var: "Kasus, sætningsled og semantiske roller". Denne titel er for mig at se udtryk for et traditionelt, deskriptivt syn på sproglige beskrivelser: først afklares konstruktionens kasusforekomster, og disse forekomster leder automatisk til udpegelse af en række konstituenter. For at forstå, hvad sætningen betyder, trækkes de semantiske roller op af hatten, og dermed anses konstruktionen for beskrevet (og forstået). Af grunde, som er redegjort for i det ovenstående, har jeg plæderet for en nytænkning af den sproglige beskrivelse, og denne nytænkning ville i givet fald medføre en revidering af lingvistkollokviets titel: "Sætningsled og kasus". Med denne titel afskaffes de semantiske roller, og titlen forudsætter, at en adækvat, formal sproglig beskrivelse bedst tager udgangspunkt i den generelle syntaks for derefter at afklare de sprogspecifikke kasusforekomster i den enkelte konstruktion. En sådan beskrivelse ville med en formalt defineret teori i ryggen kunne hjælpe til afklaring af mere generelle, sproglige problemstillinger, som ligger ud over mulighederne for den deskriptive beskrivelse. Ud fra mit teoretiske ståsted mener jeg derfor, at titlen for lingvistkollokviet burde revideres.

\section{LITTERATUR}

Bolt-Jørgensen, Henrik (1998), In angulo cum libello I, Svendborg: Forlaget Mørch \& Wagner, 1. udgave, 1. oplag.

Bresnan, Joan (2001), Lexical-Functional Syntax, Oxford / Massachusetts: Blackwell Publishers. 
Chomsky, Noam (1981), Lectures on Government and Binding, Dordrecht: Forlis Publications.

Chomsky, Noam (1995), The Minimalist Program, Massachusetts: The MIT Press.

Chomsky, Noam (2000), New Horizons in the Study of Language and Mind, Cambridge, England: Cambridge University Press.

Crystal, David 1980 (1997), A Dictionary of Linguistics and Phonetics, Oxford: Blackwell Publishers, 4. udgave.

Diderichsen, Paul 1946 (1971), Elementoer Dansk Grammatik, København: Gyldendals Forlag, 3. udgave, 5. oplag.

Dik, Simon C. (1997), The theory of functional grammar. Part 1, The Structure of the Clause, Berlin/New York: Monton de Gruyter, second, revised edition.

Fillmore, Charles J. (1968), “The Case For Case”, in: Bach, Robert T. Harms (eds.), (1968) Universals in Linguistic Theory, London: Holt, Rinehart and Winston, pp. 1-88.

Götzsche, Hans (1994), Deviational Syntactic Structures. A Contrastive Linguistic Study in the Syntax of Danish and Swedish, Institutionen för svenska språket, Göteborgs universitet.

Götzsche, Hans (1998), “Om satsadverbial i svenska”, indleveret som manuskript til konferenceudgivelsen ved Svenskans beskrivning 23, pp. 143-150.

Götzsche, Hans (2005a), An Introduction to Formative Grammar: The Theory of EpiFormal Analysis in Syntax $(E F A(X)$ 2), (on-line publication): [http://www.cfl.hum.aau.dk/linguistics/index.html]

Götzsche, Hans (2005b), EFA(X)2: Definitions and formalisms, (on-line publication): [http://www.cfl.hum.aau.dk/linguistics/index.html]

Hjelmslev, Louis 1943 (1993), Omkring Sprogteoriens Grundloeggelse, København: The Linguistic Circle of Copenhagen.

Honderich, Ted (1995), The Oxford Companion to Philosophy, Oxford: Oxford University Press.

Jørgensen, Peter (1970), Tysk Grammatik, Bind 2, København: G. E. C. Gads forlag, 4. oplag.

Kristensen, Susanne Annikki (2001), Morfologiske syntaktiske strukturer. Om en morfologisk variant af Den Epi-Formale Syntaksteori formuleret på baggrund af tyrkisk og finsk, Specialeafhandling ved Aalborg Universitet.

Kristensen, Susanne Annikki (2004), Syntagmatiske Strukturer. Frasestrukturelle beskrivelser af adverbielle udtryk $i$ dansk og finsk, indleveret som ph.d.afhandling og forsvaret ved Aalborg Universitet. Afhandlingen kan frit hentes fra: [http://www.kommunikation.aau.dk/phd/annikki/afhandling.pdf]

Maegaard, Bente, Henrik Prebensen, Carl Vikner (1975), Matematik og Lingvistik, Odense: Odense Universitetsforlag.

Matthews, Peter H. (1997), The Concise Oxford Dictionary of Linguistics, Oxford University Press.

Milling, Lone, Elisabeth Nedergaard, Heine Norsk (2004), Fra ord til saetning. En introduktion til almen grammatik, Århus: Forlaget Systime, 1. udgave, 1. oplag. 
Neidle, Carol (1996), "Lexical Functional Grammar", in: Brown, Keith, Jim Miller (eds.), (1996) Concise Encyclopedia of Syntactic Theories, Oxford: Elsevier, pp. 223-231.

Olsen, Lennert, Birgitte Hertling (1988), Grønlandsk tilhoengsliste, Nuuk: Pilersuiffik.

Platzack, Christer (1998), Svenskans inre Grammatik - det minimalistiska programmet. En introduktion til modern generativ grammatik, Lund: Studentlitteratur.

Saussure, Ferdinand de 1916 (1955), Cours de Linguistique Générale, Paris: Payot.

Whaley, Lindsay J. (1997), Introduction to Typology. The Unity and Diversity of Language, Thousand Oaks / London / New Delhi: Sage Publications.

\section{NOTER}

1 En liste over anvendte forkortelser på grammatiske termer findes i appendikset.

2 Analysen af laetae som et adverbial kunne nok have givet anledning til diskussion mellem forfatteren og Paul Diderichsen, idet Diderichsen ville betegne leddet som et frit prædikativ (Diderichsen 1946 (1971): 176). Jeg er imidlertid en smule skeptisk over for termen "frit prædikativ", idet leddet alene defineres ved, at det i modsætning til et fast prædikativ kan fjernes uden en modifikation af verbets betydning og tryk. Tillige karakteriseres det frie prædikativ som en "tilstandsbetegnelse" og dermed er vi ovre i adverbialets funktion, hvorfor vi af teoretiske grunde med fordel kan betegne leddet som et adverbial.

3 Afsnittet er en revideret udgave af kapitel 2 og 3 i min ph.d.-afhandling (2004).

4 Begrebet 'X-bar-system' er hentet fra Platzack (1998), mens Chomsky selv anvender begrebet 'X-bar theory' (Chomsky 1995). Platzacks begreb foretrækkes frem for Chomskys, idet jeg i tilslutning til Honderichs teoridefinition ikke er villig til at kalde $\mathrm{X}$-bar-repræsentationen for en videnskabelig teori i strengeste forstand:

A scientific theory is an attempt to bind together in a systematic fashion the knowledge that one has in a particular aspect of the world of experience. The aim is to achieve some form of understanding, where this is usually cashed out of explanatory power and predictive fertility. [...] one has sets of laws bound together through the fact that, from a few high-powered axioms or hypotheses, everything else can be shown to follow as a deductive consequence. Explanation therefore is a matter of showing how things happened because of the laws of the theory. Prediction is a matter of showing how things will happen in accordance with the laws of the theory. (Honderich 1995: 870)

Ud fra denne definition må Chomskys 'X-bar-system' snarere betragtes som et system eller en model til beskrivelse af strukturer, som opstilles på baggrund af den overordnede teori, og hvis evne til forklaring netop skal findes i den overordnede teori.

5 Der er tidligere i forbindelse med reference forekommet en anden adverbialdefinition, men eftersom denne definition siden er blevet revideret (jf. Kristensen 2004), optræder her den nyeste udgave.

6 Forskellen på j- og g-indekserne er, at et j-indeks ville kunne specificeres eller gøres til habitat, mens dette ikke er tilfældet for et g-indeks (jf. Kristensen 2004: 123). 


\section{APPENDIKS}

Oversigt over anvendte grammatiske termer

( ) parentes angiver, at den morfologiske information angives gennem en manglende form, svarende til Ø-morfem i traditionel forstand.

3

a

g

$\mathrm{h}$

j

o

s

$\mathrm{V}$

sp

det

nom

vrb

vqa

accv

adev

$\mathrm{advb}$

artl

genv

indf

indv

nomv

nomn

parv

plur

pres

pret

sing

verb
3. person

adverbial

indeks; adled i en frase; kan ikke selv optræde som kerne

habitat; kerne i en frase

indeks; adled i en frase; kan selv optræde som kerne

objekt

subjekt

verbal

subjektsprædikativ

determiner; komponent $\mathrm{i}$ en frase med en nom-komponent som kerne.

substantivisk komponent; kerne i en nominalfrase

verbal-komponent, del af en verbalfrase

verbalt-kvasiadverbium, komponent i en verbalfrase

akkusativ

adessiv

adverbium

artikel

genitiv

indefinit

indikativ

nominativ

substantiv

$$
\text { partitiv }
$$

pluralis

præsens

præteritum

singularis

verbum 